\title{
Daya Dukung dan Laju Pertumbuhan Microcystis Hasil Isolasi dari Waduk Sutami pada Berbagai Variasi Konsentrasi Nitrat dan Fosfat dalam Medium Selektif B-12
}

\section{Carrying Capacity and Growth Rate of Isolated Microcystis from Sutami Reservoir on Some Nitrate and Phosphate Concentrations in B-12 Selective Medium}

\author{
Catur Retnaningdyah ${ }^{1 *}$, Suharjono ${ }^{1}$, Agoes Soegianto², dan Bambang Irawan ${ }^{2}$ \\ ${ }^{1}$ Jurusan Biologi, Fakultas MIPA, Universitas Brawijaya, Jl. Veteran Malang Jawa Timur 65145 \\ ${ }^{2}$ Departemen Biologi, Fakultas Sains dan Teknologi, Universitas Airlangga Surabaya \\ E-mail: catur@ub.ac.id* penulisuntuk korespondensi
}

\begin{abstract}
The main objective of this research was to calculate the carrying capacity and growth rate of isolated Microcystis result in Sutami reservoir on a variety of nitrate and phosphate concentrations in the B-12 selective medium. Research was conducted in the laboratory with pure experiments using completely randomized factorial design with factors of nitrate concentration variation $(8,16,32$, and $64 \mathrm{ppm})$ and phosphate $(0.2,0.4,0.8$ and $1.6 \mathrm{ppm})$ in $\mathrm{B}-12$ medium. Repetition of the study was conducted three times at the same time. Microcystis population abundance which was counted every day until the stationary phase (day \pm 30 ) was used to calculate the rate of growth $(\beta)$ and maximum abundance of Microcystis can be supported by each medium treatment $(\gamma)$. The results showed that the growth rate of Microcystis was not significantly influenced by levels of phosphate in the medium but significantly positively correlated with increasing nitrate concentration in the medium. Carrying capacity or the maximum abundance $(\gamma)$ of Microcystis was influenced by the combination of nitrate and phosphate in the B12 medium. Concentration of phosphate $0.4 \mathrm{ppm}$ in medium combined with nitrate 8-64 ppm could support the highest abundance of Microcystis.
\end{abstract}

Key words: Microcystis, B-12 medium, nitrate and phosphate, Sutami Reservoir

Abstrak

Penelitian ini bertujuan menghitung daya dukung dan laju pertumbuhan Microcystis hasil isolasi dari waduk Sutami pada berbagai variasi konsentrasi nitrat dan fosfat dalam medium selektif B 12. Penelitian dilakukan di laboratorium dengan eksperimen murni menggunakan rancangan acak lengkap faktorial dengan faktor berupa variasi konsentrasi nitrat $(8,16,32$, dan $64 \mathrm{mg} / \mathrm{L})$ dan fosfat $(0,2 ; 0,4 ; 0,8 ;$ dan $1,6 \mathrm{mg} / \mathrm{L})$ pada medium B12. Pengulangan penelitian dilakukan tiga kali pada waktu yang sama. Hasil penghitungan kelimpahan populasi Microcystis tiap hari sampai fase stasioner $( \pm 30$ hari) digunakan untuk menghitung laju pertumbuhan $(\beta)$ dan kelimpahan maksimum Microcystis yang bisa didukung oleh tiap medium perlakuan $(\gamma)$. Hasil penelitian menunjukkan bahwa laju pertumbuhan tidak secara nyata dipengaruhi oleh kadar fosfat dalam medium tetapi secara nyata berkorelasi positif dengan peningkatan konsentrasi nitrat dalam medium. Daya dukung atau kelimpahan maksimum $(\gamma)$ Microcystis tidak secara nyata dipengaruhi oleh interaksi variasi konsentrasi nitrat dan fosfat di medium. Konsentrasi fosfat 0,4 mg/L yang dikombinasikan dengan nitrat 8-64 mg/L mampu mendukung kelimpahan maksimum Microcystis tertinggi.

Kata kunci: Microcystis, medium B12, nitrat dan fosfat, Waduk Sutami

Diterima: 01 Maret 2010, disetujui: 28 September 2010 


\section{Pendahuluan}

Waduk Sutami (Karangkates) terletak di Kecamatan Sumberpucung, Kabupaten Malang, Jawa Timur. Waduk ini bersifat multifungsi di antaranya untuk pembangkit tenaga listrik, rekreasi, dan perikanan. Hasil pemantauan terhadap kualitas air Waduk Sutami menunjukkan bahwa perairan tersebut sudah mengalami etrofikasi dan tercemar oleh bahan organik. Pada tahun 2002 di perairan tersebut pernah terjadi peledakan (blooming) populasi mikroalga dari jenis Microcystis (Retnaningdyah et al., 2002). Berdasarkan hasil monitoring selama tahun 2004 sampai bulan Maret 2006 ditemukan bahwa Microcystis bersama-sama dengan Synedra sp. dan Ceratium sp. selalu ada dalam kelimpahan yang tinggi di Waduk Sutami (Samino dan Retnaningdyah, 2004; Retnaningdyah dan Samino, 2005; 2006). Ledakan populasi Microcystis sering terjadi pada waktu dan lokasi tertentu di Waduk Sutami mengakibatkan kematian ikan yang hidup di perairan tersebut (Samino dan Retnaningdyah, 2006).

Microcystis merupakan sianobakteria yang biasa tumbuh di permukaan air. Pada kondisi yang normal Microcystis ini tidak berbahaya bagi organisme lain atau manusia. Pada kondisi tertentu seperti di musim panas dengan nutrien yang tinggi jenis ini tumbuh secara cepat yang biasa disebut algae blooms. Pada kerapatan yang sangat tinggi maka angin dapat meniup koloni ini menuju ke tepi perairan dan membentuk lapisan yang sangat rapat. Microcystis sp. pada kondisi blooming dapat menghasilkan racun disebut microcystin yang mempunyai sifat toksik tinggi baik terhadap tumbuhan maupun hewan sampai menyebabkan kematian (RomanowskaDuda et al., 2002; Ferrão-Filho et al., 2002; Oberholster et al., 2004; Closs et al., 2006; Samino dan Retnaningdyah, 2006 ).

Pengendalian terhadap blooming Microcystis yang sedang terjadi di perairan dapat dilakukan apabila faktor-faktor penyebab blooming telah diketahui yaitu dengan mengoptimalkan mikroba insitu yang berpotensi secara efektif dapat mereduksi bahan pencemar penyebab blooming. Akan tetapi, penelitian tentang faktor lingkungan yang menyebabkan terjadinya blooming di perairan daerah tropik belum diteliti. Analisis jalur (path analyses) untuk mengetahui keterkaitan Microcystis dengan kualitas fisiko-kimiawi air Waduk Sutami yang telah dilakukan oleh Retnaningdyah (2008) menunjukkan peningkatan parameter total P dan $\mathrm{N}$ serta kelimpahan fitoplankton yang lain dapat mendorong peningkatan kelimpahan Microcystis di Waduk Sutami.

Hasil penelitian di daerah subtropik masih menjadi kontroversial. Smith (1983); Fujimoto dan Sudo (1997) menemukan bahwa blooming sianobakteria cenderung terjadi pada danau dengan nisbah massa Total Nitrogen dibanding Total fosfor (TN:TP) kurang dari 29 yang secara umum disebut sebagai "pengaturan TN:TP". Hasil penelitian Stahl-Delbanco et al., (2003) di Swedia menunjukkan bahwa blooming Microcystis dipengaruhi oleh Microcystis pada fase dorman (resting stages) yang dipicu oleh tingginya konsentrasi nutrien dalam kombinasi nisbah massa $\mathrm{N}: \mathrm{P}$ (kombinasi nitrogen anorganik terlarut dengan total fosfor) kurang dari 10 . Adapun penelitian Xie et al., (2003) di danau hipereutrofik China mendapatkan hasil yaitu rendahnya nisbah TN:TP bukan merupakan penyebab blooming Microcystis tetapi sebagai hasil atau akibat dari blooming tersebut. Dijelaskan pula bahwa blooming dapat terjadi pada nisbah TN:TP < 29 atau TN:TP > 29 dengan nutrien ( $\mathrm{N}, \mathrm{P})$ yang cukup tinggi. Blooming tidak dapat terjadi pada perairan dengan konsentrasi $\mathrm{P}$ yang rendah meskipun keberadaan $\mathrm{N}$ mencukupi.

Berdasarkan hasil penelitian di atas terutama adanya perbedaan hasil dalam hal nisbah N:P pemicu blooming Microcystis hasil di lokasi penelitian daerah subtropik dan belum adanya informasi penelitian dalam kajian yang sama di daerah tropik, maka tujuan penelitian ini untuk mengetahui respons pertumbuhan populasi Microcystis dengan menghitung daya dukung dan laju pertumbuhan Microcystis yang diisolasi dari waduk Sutami pada berbagai variasi konsentrasi nitrat dan fosfat dengan menggunakan medium selektif B-12 di laboratorium. Untuk selanjutnya, hasil ini diharapkan dapat dipakai sebagai landasan penelitian berikutnya terutama dalam hal penentuan nilai ambang nitrat dan fosfat pemicu blooming dan juga tindakan dalam rangka pengendalian blooming Microcystis di perairan. 


\section{Metode Penelitian}

Penelitian ini merupakan eksperimen murni di laboratorium menggunakan rancangan acak lengkap faktorial. Sebagai faktor pertama adalah perlakuan variasi konsentrasi nitrat pada medium B-12 (8, 16, 32, $64 \mathrm{mg} / \mathrm{L})$ dan tanpa penambahan nitrat sebagai kontrol. Faktor kedua adalah variasi konsentrasi fosfat pada medium B-12 $(0,2 ; 0,4 ; 0,8 ; 1,6 \mathrm{mg} / \mathrm{L})$ dan tanpa pemberian fosfat sebagai kontrol. Variasi konsentrasi ini ditentukan berdasarkan hasil penelitian sebelumnya (Retnaningdyah et al., 2007). Perlakuan penelitian dengan ulangan 3 kali. Perlakuan variasi konsentrasi nitrat dan fosfat tersebut dilakukan dalam medium B-12. Medium ini dipakai karena terbukti dapat mengakibatkan pertumbuhan Microcystis yang lebih baik dibandingkan dengan medium selektif yang lain (Retnaningdyah et al., 2008).

$$
\text { Pengambilan sampel Microcystis }
$$

dilakukan di Waduk Sutami Malang, Jawa Timur. Pembuatan medium B-12 dilakukan di Laboratorium Mikrobiologi, sedangkan inkubasi penelitian dilakukan di Laboratorium Ekologi dan Diversitas Hewan Jurusan Biologi Fakultas Matematika dan Ilmu Pengetahuan Alam Universitas Brawijaya Malang. Beberapa parameter kualitas air (Total Kjeldahl $\mathrm{N}$ dan total P) diukur di Laboratorium Perum jasa Tirta I Malang. Penelitian dilakukan bulan April sampai November tahun 2009.

Sampel Microcystis dari Waduk Sutami disaring menggunakan saringan nylon (ukuran 406 pori-pori per inci) dan dibilas dengan larutan garam fisiologis $(\mathrm{NaCl}$ 0,85\%) steril untuk mempertahankan kondisi sel-sel Microcystis selama penyaringan. Secara aseptis, koloni Microcystis yang telah tersaring dipilih di bawah mikroskop dan dimasukkan ke dalam medium B12 kemudian dihitung kepadatan Microcystis hingga diperoleh $5 \times 10^{7}$ sel.mL $\mathrm{m}^{-1}$. Kultur ini digunakan sebagai stok inokulum.

Uji respon pertumbuhan Microcystis dilakukan dalam medium B-12 yang dimodifikasi berdasarkan perlakuan penelitian di atas. Stok inokulum Microcystis sebanyak 15\% dari volume total medium (dengan kelimpahan \pm $2 \times 10^{6} \mathrm{sel} / \mathrm{mL}$ ) dimasukkan ke dalam botol yang telah berisi medium kaldu B-12 steril yang telah dimodifikasi berdasarkan perlakuan di atas
(Pasteur, 2007). Volume total dari medium B-12 yang dipakai untuk tiap-tiap perlakuan adalah $2000 \mathrm{~mL}$. Inkubasi dilakukan sampai diperoleh fase pertumbuhan stasioner (sekitar 15 hari) pada suhu ruang dengan intensitas cahaya yang dijaga pada kisaran 5000-8000 Lux (lampu neon OSRAM 23 Watt) secara terus menerus 12 jam per hari (Retnaningdyah et al., 2008). Teknik kultur yang digunakan dalam penelitian ini adalah batch culture. Kelimpahan Microcystis dihitung setiap hari. Adapun kualitas medium seperti kadar aktual nitrat, ortofosfat, amonium, total Kjeldahl $\mathrm{N}$ dan total $\mathrm{P}$ medium perlakuan diukur setiap empat hari. Penentuan kualitas medium tersebut diukur menurut Clesceri et al., (1998).

Penghitungan sel Microcystis pada kultur stok inokulum dan kultur perlakuan dilakukan menurut Joung et al., (2006). Penghitungan jumlah sel menggunakan hemositometer dan mikroskop binokuler (Olympus) pada perbesaran 400x. Sel Microcystis yang dihitung adalah yang terdapat dalam satu kotak besar hemositometer dengan volume $1 \times 10^{4} \mathrm{~cm}^{3}$.

Data kelimpahan Microcystis digunakan untuk menghitung laju pertumbuhan $(\beta)$ dan daya dukung $(\gamma)$ atau kelimpahan maksimum Microcystis yang dapat didukung oleh medium perlakuan. Untuk mengetahui nilai $\beta$ dan $\gamma$ tersebut terlebih dahulu dibuat model kurva pertumbuhan Microcystis dengan membuat kurva standar nonlinear dalam bentuk kurva logistik atau sigmoid yang dilakukan dengan program Genstat for Windows dengan rumus:

$$
Y_{i}=\alpha+\frac{\gamma}{1+e^{\left(-\beta\left(X_{i}-\mu\right)\right.}}+\xi_{i}
$$

Keterangan :

$Y_{i}$ : Kelimpahan Microcystis pada waktu ke-i

$\alpha$ : Rata-rata jumlah awal Microcystis (Asimtot yang paling rendah)

$\gamma$ : Kelimpahan Microcystis maksimum yang didukung oleh lingkungan (daya dukung)

e : 2,71828

$\mu:$ Konstanta

$\beta$ : Laju pertumbuhan intrinsik Microcystis pada potensi biotik

$X_{i}$ : Waktu yang digunakan untuk pertumbuhan (dari 0 sampai ke-i)

Perbedaan laju pertumbuhan $(\beta)$ dan kelimpahan maksimum Microcystis $(\gamma)$ 
antarperlakuan diketahui dari uji Anova yang dilanjutkan dengan uji Tukey HSD yang dilakukan dengan paket program SPSS for Windows release 13 .

\section{Hasil dan Pembahasan}

Kelimpahan awal sel Microcystis yang dipakai untuk tiap perlakuan berkisar antara 5-9 $\mathrm{x} 10^{5} \mathrm{sel} / \mathrm{mL}$. Perlakuan pemberian nitrat $8-64$ $\mathrm{mg} / \mathrm{L}$ di medium B-12 mampu meningkatkan kelimpahan sel Microcystis dengan baik. Peningkatan kelimpahan sel Microcystis sampai hari ke-15 menunjukkan pola yang hampir sama pada setiap perlakuan, tetapi setelah hari tersebut terlihat adanya perbedaan respons pertumbuhan. Pemberian kadar fosfat $0,4 \mathrm{mg} / \mathrm{L}$ pada tiap-tiap perlakuan nitrat mengakibatkan peningkatan kelimpahan sel Microcystis yang lebih tinggi dibandingkan dengan pemberian kadar fosfat yang lain.

Rata-rata nilai daya dukung atau kelimpahan maksimum sel Microcystis yang bisa didukung oleh tiap-tiap medium perlakuan $(\gamma)$ dan juga laju pertumbuhan intrinsik $(\beta)$ yang dihitung dari pengamatan harian kelimpahan Microcystis tiap perlakuan berdasarkan rumus pertumbuhan dapat dilihat pada Gambar 1 . Medium B-12 yang diberi nitrat dan fosfat dengan kadar yang bervariasi dapat mengakibatkan laju pertumbuhan dan mendukung kelimpahan sel Microcystis maksimum yang berbeda pula.

Berdasarkan uji Anova, kelimpahan maksimum Microcystis $(\gamma)$ yang bisa didukung oleh medium perlakuan nyata dipengaruhi oleh kombinasi nitrat $(\mathrm{N})$ dan fosfat $(\mathrm{P})$ perlakuan (Gambar 1). Pemberian fosfat di medium B12 sebesar $0,4 \mathrm{mg} / \mathrm{L}$ yang dikombinasikan dengan nitrat konsentrasi 8-64 $\mathrm{mg} / \mathrm{L}$ dapat mengakibatkan daya dukung terhadap kelimpahan Microcystis tertinggi (nilai $\gamma$ 4,15$6,51 \times 10^{6} \mathrm{sel} / \mathrm{mL}$ ) dibanding dengan kombinasi fosfat dan nitrat perlakuan yang lain (nilai $\gamma$ $1,85-4,25 \times 10^{6} \mathrm{sel} / \mathrm{mL}$ ). Uji korelasi menunjukkan bahwa kadar fosfat pada tiap-tiap perlakuan nitrat secara nyata berkorelasi dengan kelimpahan maksimum Microcystis yang bisa didukung oleh medium perlakuan dengan nilai $\mathrm{R}^{2}=1$ (Gambar $\left.2 \mathrm{a}\right)$.
Laju pertumbuhan $(\beta)$ hanya dipengaruhi oleh variasi pemberian nitrat di medium. Hasil anova yang dilanjutkan dengan uji Tukey HSD terhadap laju pertumbuhan menunjukkan bahwa penambahan nitrat $64 \mathrm{mg} / \mathrm{L}$ di medium B12 dapat mengakibatkan laju pertumbuhan Microcystis tertinggi (rata-rata 0,38 Sel.mL ${ }^{1}$.Hari ${ }^{-1}$ ) dibandingkan dengan penambahan nitrat dengan kadar yang lebih rendah $(0,23-0,33$ Sel. $\mathrm{mL}^{-1} \cdot$ Hari $\left.^{-1}\right)$. Hasil uji regresi menunjukkan bahwa semakin tinggi kadar nitrat yang diberikan secara nyata dapat meningkatkan laju pertumbuhan Microcystis di medium B12 (Gambar 2 b).

Berdasarkan uraian di atas kelimpahan maksimum Microcystis yang tinggi di medium B12 terjadi pada kadar nitrat antara $8-64 \mathrm{mg} / \mathrm{L}$, dan kadar fosfor yang rendah $(0,4 \mathrm{mg} / \mathrm{L})$. Laju pertumbuhan Microcystis yang tinggi diperoleh apabila kadar nitrat di medium semakin tinggi. Hal ini sesuai dengan pendapat Sharpley (2003), bahwa di ekosistem perairan unsur fosfor (P) merupakan nutrien pembatas yang dibutuhkan untuk pertumbuhan oleh alga pada konsentrasi yang kecil. Menurut Radojevic dan Bashkin (1999), nisbah penyerapan nutrien oleh organisme antara nitrogen dan fosfor adalah 16:1. Oleh karena itu, di ekosistem perairan unsur fosfor merupakan nutrien pembatas dalam eutrofikasi. Hal tersebut berarti percepatan eutrofikasi tidak akan terjadi apabila ketersediaan fosfor rendah, walaupun kelimpahan nitrogen tinggi. Selain itu fosfor merupakan pendorong kegiatan pengikatan nitrogen bagi alga. Jika ketersediaan fosfor mencukupi, peningkatan konsentrasi nitrat akan memicu terjadinya blooming alga (Soeprobowati dan Hadisusanto, 2009). Akan tetapi, apabila seluruh fosfor habis digunakan pertumbuhan organisme akan terhenti walaupun nutrien lain melimpah. Dokulil dan Teubner (2000) juga menambahkan bahwa salah satu penyebab blooming Microcystis adalah tingginya nitrat. Adapun menurut Ramirez dan Bicudo (2005), Microcystis merupakan bioindikator untuk daerah perairan yang bersifat etrofik dengan kadar nitrat yang tinggi, karena organisme ini memanfaatkan nitrat yang digunakan sebagai sumber energi dalam menghasilkan sel-sel baru dan koloni. 


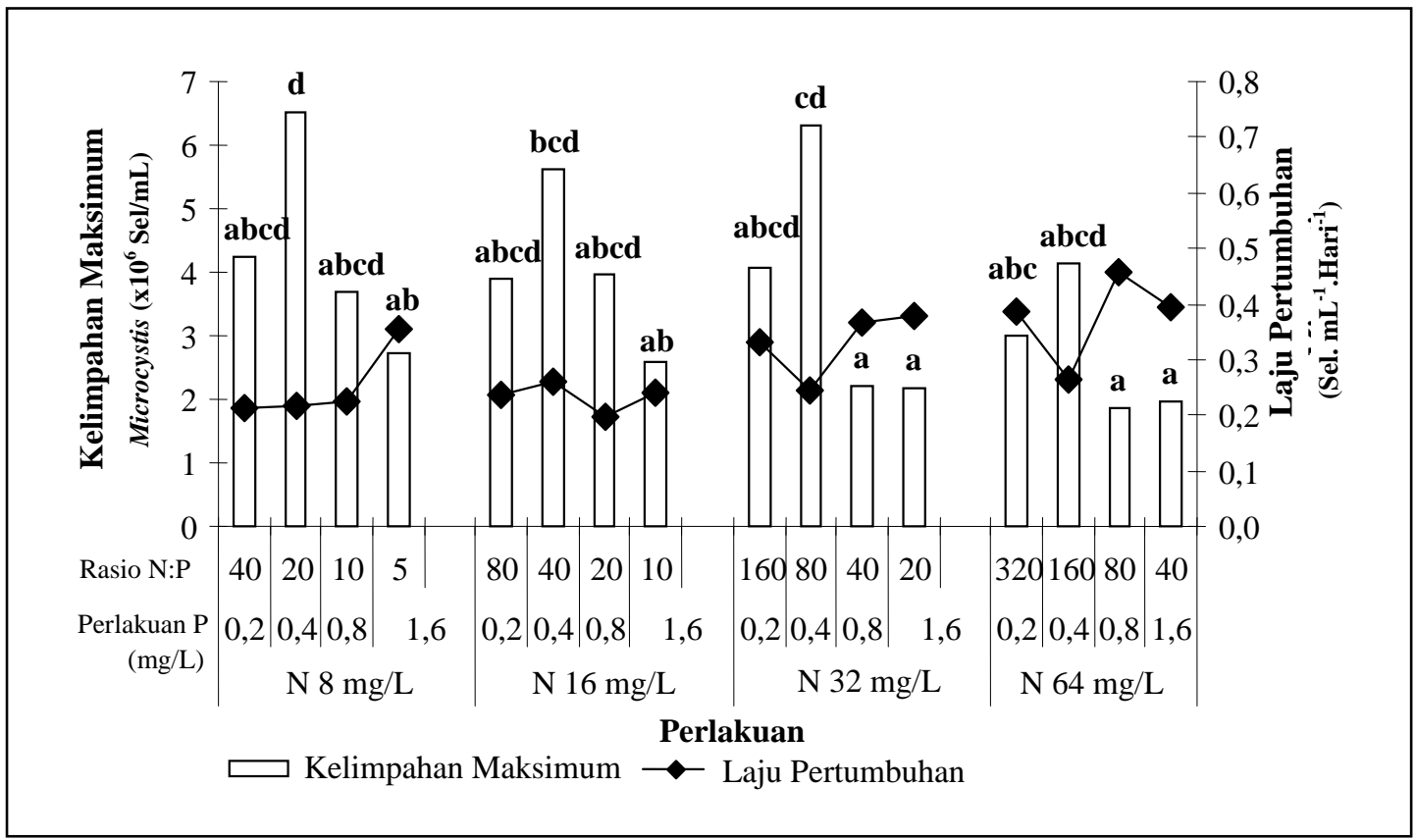

Gambar 1. Rata-rata daya dukung (kelimpahan maksimum) Microcystis $(\gamma)$ dan laju pertumbuhan Microcystis $(\beta)$ pada setiap perlakuan pemberian Nitrat $(\mathrm{N})$ dan Fosfat $(\mathrm{P})$ di medium B12.

Keterangan: (a) Huruf yang sama menunjukkan tidak berbeda nyata kelimpahan maksimum Microcystis berdasarkan uji Tukey HSD dengan $\alpha 0,05$.
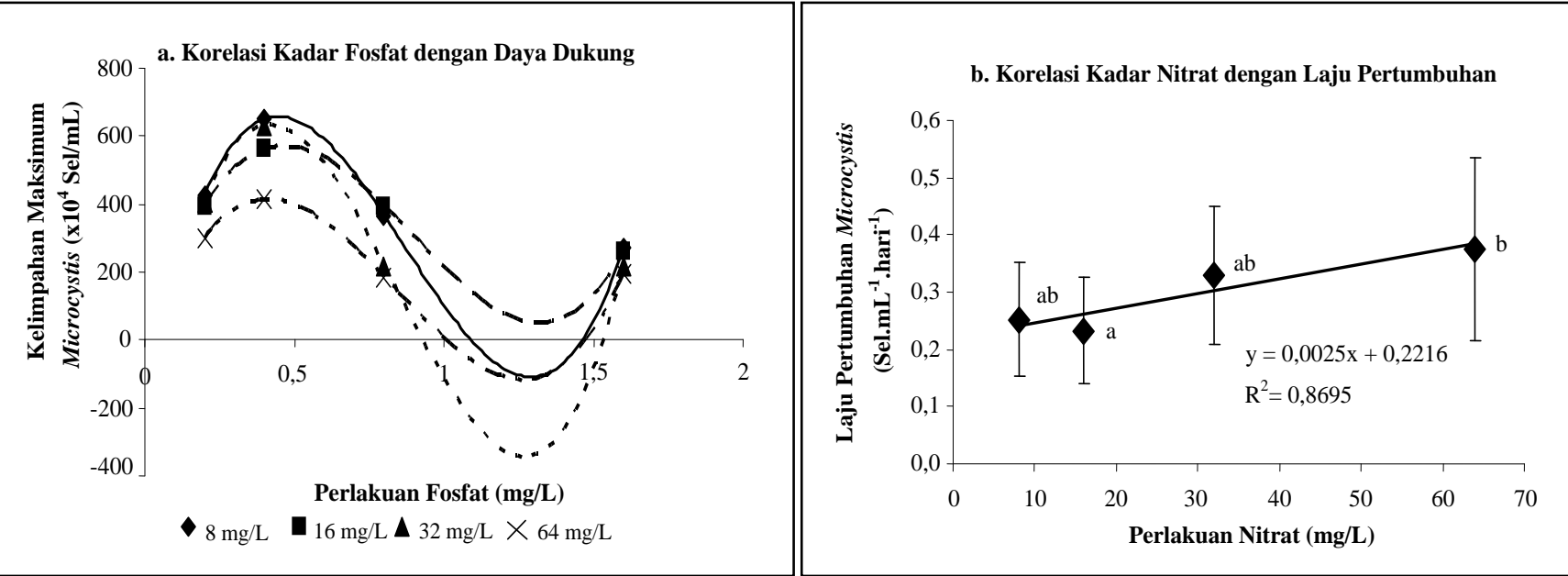

Gambar 2. Korelasi kadar fosfat di medium B12 terhadap daya dukung Microcystis (a) dan korelasi kadar nitrat di medium B12 terhadap laju pertumbuhan Microcystis (b).

Keterangan: (a) Rumus persamaan: $\mathrm{Y}_{8}=2539,6 \mathrm{X}^{3}-6619,4 \mathrm{X}^{2}+4390,6 \mathrm{X}-208,59 ; \mathrm{Y}_{16}=1678,2 \mathrm{X}^{3}-491 \mathrm{X}^{2}+3089 \mathrm{X}-$ 61,$392 ; Y_{32}=3181,7 X^{3}-8051,2 X^{2}+5068,2 X-311,64 ; \quad Y_{64}=1716,1 X^{3}-4314,9 X^{2}+2680,3 X-76,319$ dengan nilai R2 tiap persamaan adalah 1 (b) Huruf yang sama menunjukkan tidak berbeda nyata nilai laju pertumbuhan berdasarkan uji Tukey HSD dengan $\alpha 0,05$. 
Daya Dukung dan Laju Pertumbuhan Populasi Microcystis Hasil Isolasi dari Waduk Sutami pada Kontrol Perlakuan

Medium B-12 yang tidak diberi nutrien nitrat tetapi hanya diberi fosfat dapat menghambat pertumbuhan Microcystis yang ditunjukkan dengan laju pertumbuhan intrinsik ( $\beta$ ) yang negatif $\left(-0,20\right.$ sel.mL $\mathrm{m}^{-1}$.Hari ${ }^{-1}$ sampai 0,53 sel. $\mathrm{mL}^{-1}$. Hari $\left.{ }^{-1}\right)$, meskipun kelimpahan sel maksimum yang bisa didukung oleh medium tersebut nyata semakin tinggi dengan semakin tingginya kadar fosfat di medium dengan kelimpahan berkisar antara $5,9-9,1 \times 10^{5} \mathrm{sel} / \mathrm{mL}$. Sebaliknya pemberian nitrat $8-64 \mathrm{mg} / \mathrm{L}$ yang tidak dibarengi dengan pemberian fosfat ternyata masih mampu mendukung pertumbuhan Microcystis dengan nilai laju pertumbuhan antara $0,21-0,46$ sel.mL $L^{-1}$.Hari ${ }^{-1}$, meskipun kelimpahan sel maksimum yang bisa didukung oleh medium ini lebih rendah berkisar antara $6,9-11,8 \times 10^{5} \mathrm{sel} / \mathrm{mL}$ dibandingkan dengan yang diberi fosfat berkisar antara $1,85-6,51 \times 10^{6}$ $\mathrm{sel} / \mathrm{mL}$.

\section{Pengaruh Nisbah Nitrat terhadap Fosfat pada Daya Dukung dan Laju Pertumbuhan Populasi Microcystis Hasil Isolasi dari Waduk Sutami}

Hasil uji Anova menunjukkan bahwa nisbah nitrat terhadap fosfat (Nitrat:Fosfat) secara nyata berpengaruh terhadap kelimpahan maksimum Microcystis di medium B12 dan tidak berpengaruh terhadap laju pertumbuhannya (Gambar 1). Rasio yang sama dengan kadar nitrat dan fosfat yang berbeda dapat mendukung kelimpahan maksimum Microcystis yang berbeda pula. Kelimpahan maksimum Microcystis yang selanjutnya bisa memicu terjadinya blooming, dapat terjadi pada nisbah nitrat : fosfat 20, 40 dan 80 (Gambar 1). Pada nisbah 20 diperlukan pemberian nitrat yang rendah $(8 \mathrm{mg} / \mathrm{L})$ untuk dapat mendukung kelimpahan maksimum Microcystis paling tinggi $\left(6,51 \times 10^{6} \mathrm{sel} / \mathrm{mL}\right)$. Medium dengan rasio nitrat:fosfat 40 akan mengakibatkan kelimpahan maksimum Microcystis yang paling tinggi $\left(5,63 \times 10^{6} \mathrm{sel} / \mathrm{mL}\right)$ jika diberi nitrat $16 \mathrm{mg} / \mathrm{L}$. Sedangkan medium dengan rasio nitrat:fosfat 80 memerlukan nitrat yang tinggi yaitu $32 \mathrm{mg} / \mathrm{L}$ untuk dapat mendukung kelimpahan maksimum
Microcystis yang paling tinggi $\left(6,31 \times 10^{6}\right.$ $\mathrm{sel} / \mathrm{mL}$ ). Faktor utama yang menentukan terjadinya kelimpahan maksimum Microcystis tertinggi pada nisbah nitrat:fosfat tersebut adalah kandungan fosfat di medium. Kelimpahan maksimum tertinggi dapat terjadi pada rasio nitrat:fosfat $20, \quad 40$ maupun 80 asalkan kandungan fosfat di medium $0,4 \mathrm{mg} / \mathrm{L}$.

Hasil penelitian ini tidak sesuai dengan pendapat dari Smith (1983), Fujimoto dan Sudo (1997) tentang "pengaturan TN terhadap TP" yang menyatakan bahwa blooming cyanobacteria cenderung terjadi pada danau dengan rasio massa TN terhadap TP kurang dari 29. Hal ini juga tidak sesuai dengan pendapat StahlDelbanco et al., (2003) yang menunjukkan bahwa blooming Microcystis sp. di daerah Swedia dipicu oleh tingginya konsentrasi nutrien dalam kombinasi nisbah $\mathrm{N}$ terhadap $\mathrm{P}$ yang rendah yaitu kurang dari 10. Tetapi hasil penelitian ini lebih sesuai dengan hasil penelitian Xie et al., (2003) di danau hiperetrofik daerah China yang menunjukkan bahwa blooming Microcystis sp. dapat terjadi pada rasio TN terhadap $\mathrm{TP}<29$ atau $>29$ dengan nutrien $(\mathrm{N}$, $\mathrm{P})$ yang cukup tinggi. Blooming tidak dapat terjadi pada perairan dengan konsentrasi $\mathrm{P}$ yang rendah meskipun keberadaan $\mathrm{N}$ mencukupi.

Apabila dilihat keterkaitannya dengan kelimpahan Microcystis yang bisa didukung oleh medium dapat dilihat bahwa kelimpahan Microcystis yang tinggi akan dapat mengakibatkan rendahnya rasio aktual TN:TP (Gambar 3). Hal ini sesuai dengan hasil penelitian di danau hiperetrofik China (Xie et al., 2003) yang menunjukkan bahwa rendahnya nisbah TN terhadap TP bukan merupakan penyebab blooming Microcystis tetapi sebagai hasil dari blooming tersebut.

\section{Kualitas Medium Selama Penelitian}

Kadar nitrat yang dimanfaatkan untuk pertumbuhan hanya sedikit yang ditunjukkan dengan sedikitnya penurunan kadar nitrat di akhir perlakuan (Gambar 4). Sedangkan kadar amonium pada awal penelitian menunjukkan peningkatan dan kemudian terjadi penurunan yang signifikan. Hal ini menunjukkan bahwa bentuk nitrogen yang dipakai secara langsung untuk pertumbuhan Microcystis adalah amonium dan bukan dalam bentuk nitrat. Menurut Brower 
et al., (1990) nitrat adalah bentuk senyawa nitrogen stabil yang merupakan salah satu unsur penting untuk sintesis protein tumbuhan dan hewan. Pada konsentrasi yang tinggi nitrogen dapat menstimulasi pertumbuhan ganggang yang tak terbatas apabila beberapa syarat lain seperti konsentrasi fosfat terpenuhi (Soeprobowati dan Hadisusanto, 2009).

Hasil pengukuran kadar ortofosfat (Gambar 4) di medium pertumbuhan menunjukkan bahwa kadar tersebut di awal inkubasi sudah sesuai dengan perlakuan yang diinginkan yaitu $0 ; 0,2 ; 0,4 ; 0,8 ;$ dan $1,6 \mathrm{mg} / \mathrm{L}$. Konsentrasi ortofosfat menurun seiring dengan makin lamanya waktu inkubasi dan di akhir perlakuan menunjukkan penurunan yang signifikan. Hal ini menunjukkan bahwa fosfat dimanfaatkan secara langsung untuk pertumbuhan Microcystis selama waktu percobaan. Menurut Davis dan Masten (2004), unsur $\mathrm{P}$ merupakan nutrien vital bagi pertumbuhan alga. Oleh karena itu, apabila ketersediaan fosfor sesuai dengan kebutuhan pertumbuhannya, alga akan tumbuh cepat. Di perairan unsur fosfor umumnya berada dalam bentuk fosfat. Ortofosfat merupakan senyawa fosfat yang bersifat larut air sehingga dapat secara langsung dimanfaatkan oleh organisme.

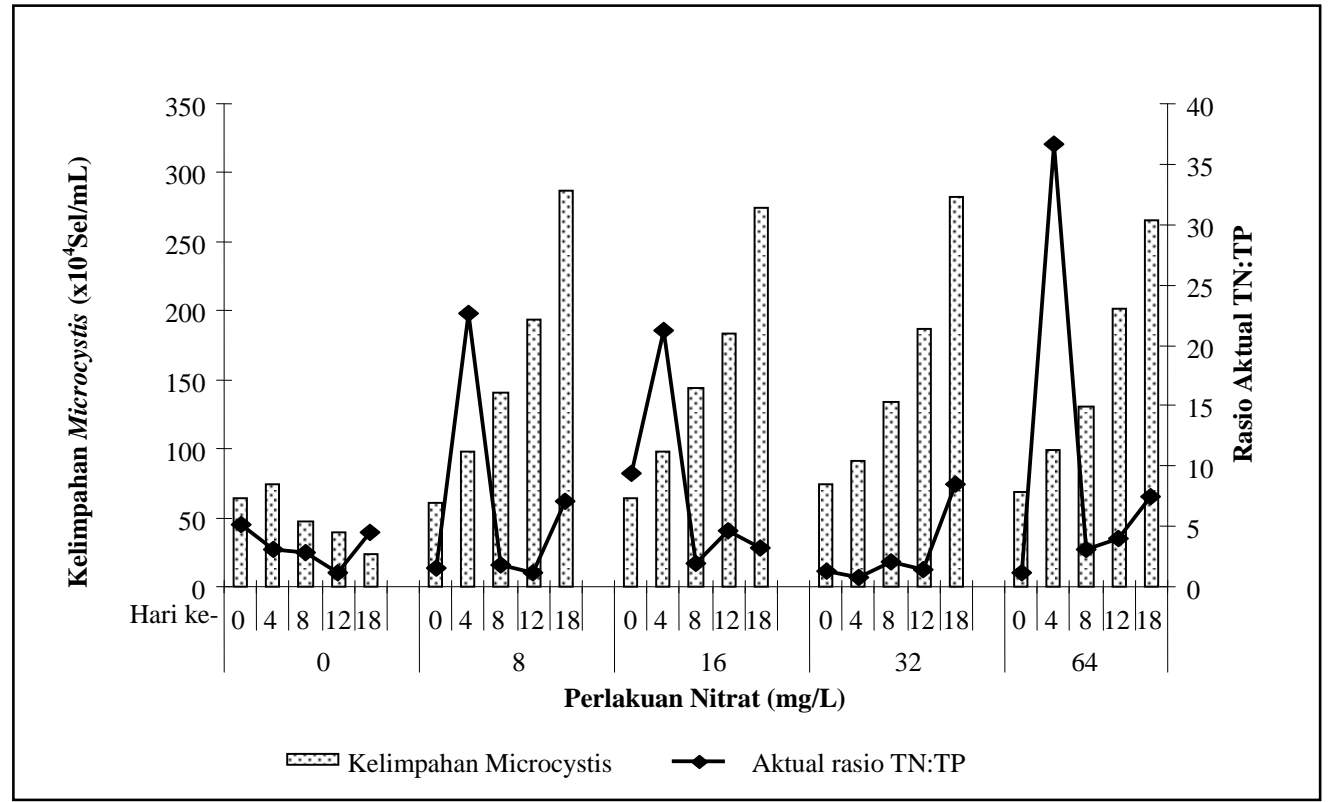

Gambar 3. Interaksi antara Nisbah aktual TN:TP dan kelimpahan Microcystis selama penelitian.

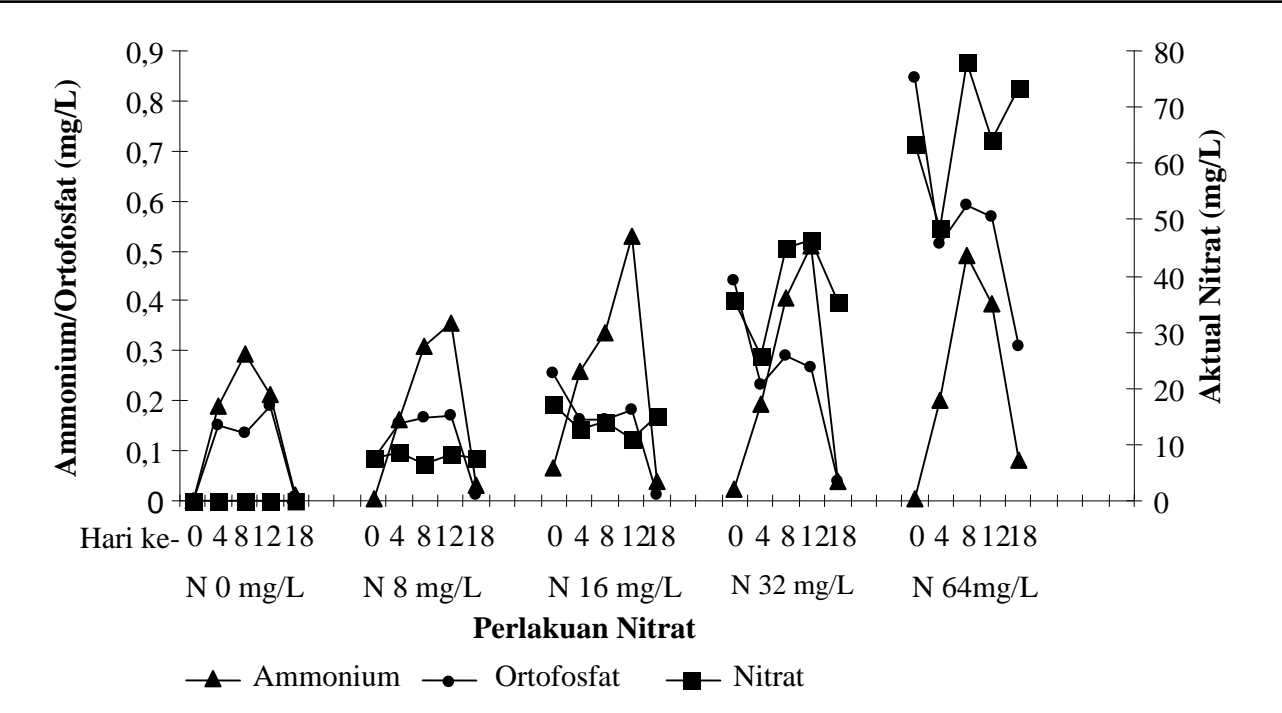

Gambar 4. Kadar ammonium, ortofosfat, dan nitrat pada perlakuan nitrat di medium selama inkubasi. 


\section{Simpulan}

Pemberian fosfat di medium B12 sebesar $0,4 \mathrm{mg} / \mathrm{L}$ yang dikombinasikan dengan nitrat konsentrasi 8-64 $\mathrm{mg} / \mathrm{L}$ dapat mendukung kelimpahan Microcystis tertinggi dibandingkan dengan kombinasi fosfat dan nitrat perlakuan yang lain. Semakin tinggi kadar nitrat di medium B12 secara nyata dapat mengakibatkan semakin tinggi laju pertumbuhan Microcystis. Blooming Microcystis di medium B12 dapat dipicu oleh kandungan nisbah nitrat : fosfat di medium sebesar 20, 40 atau 80 asalkan kandungan fosfat di medium tersebut sebesar $0,4 \mathrm{mg} / \mathrm{L}$ dan kandungan nitrat yang diberikan di medium B12 semakin tinggi seiring dengan semakin tingginya nisbah tersebut.

\section{Ucapan Terima Kasih}

Penelitian ini adalah sebagian dari Hibah Penelitian Strategis Nasional tahun anggaran 2009 yang dibiayai oleh Direktorat Jenderal Pendidikan Tinggi melalui DIPA Universitas Brawijaya, maka bersama ini diucapkan terima kasih kepada: Dirjen DIKTI, Rektor dan Lembaga Penelitian dan Pengabdian Kepada Masyarakat Universitas Brawijaya Malang.

\section{Daftar Pustaka}

Brower, J.E., Zar, J.H. dan Von Ende, C.N. 1990. Field and Laboratory Methods for General Ecology. Third Edition. Wm. C. Brown Publishers, Dubuque.

Clesceri, L.S., Greenberg, A.E. dan Eaton, A.D. 1998. Standard Methods for the Examination of Water and Waste Water. $20^{\text {th }}$ Ed., Washington.

Closs, G., Downes, B. dan Boulton, A. 2006. A Scientific Introduction Freshwater Ecology. Blackwell Publishing. Malden USA.

Davis, M.L. dan Masten, S.J. 2004. Principles of Environmental Engineering and Science. McGraw-Hill companies, Inc. New York.

Dokulil, M.T. dan Teubner, K. 2000. Cyanobacterial Dominance in Lakes. Hydrobiologia, 438: 1-12.

Ferrão-Filho, A.S., Domingos, P. dan Azevedo, S.M.F.O. 2002. Influences of a Microcystis aeruginosa Kützing bloom on zooplankton populations in Jacarepaguá Lagoon (Rio de Janeiro, Brazil). Limnologica, 32: 295-308.
Fujimoto, N. dan Sudo, R. 1997. Nutrient-limited growth of Microcystis aeruginosa and Phormidium tenue and competition under various N:P supply ratios and temperatures. Limnol. Oceanogr., 42 (2): $250-256$.

Joung, S.H., Kim, C.J., Ahn, C.Y., Jang, K.Y., Boo, S.M. dan Oh, H.M. 2006. Simple method for a cell count of the colonial Cyanobacterium Microcystis sp. J. Microbiol., 44 (5): 562-565.

Oberholster, P.J., Botha dan Grobbelaan. 2004. Microcystis spp. Source of Toxic Mikrocystins in Drinking Water. Afric J. Biotechnol., 3 (3): 159-168.

Pasteur. 2007. Medium Culture of cyanobacteria. http://www.pasteur.fr/recherche/banques/PCC/ Media.htm. 02/26/2007.

Radojevic, M. dan Bashkin, V.N. 1999. Practical Environmental Analysis. The Royal Society of Chemistry. Cambridge.

Ramirez, J.J. dan Bicudo, C.E.M. 2005. Diurnal and Spatial (Vertical) Dynamics of Nutrients (N, P, Si) in Four Sampling Days (Summer, Fall, Winter and Spring) in A Tropical Shallow Reservoir and Their Relationships with The Phytoplankton Community. Braz. J. Biol., 65 (1): 141-157.

Retnaningdyah, C., Prayitno, Y., Rosyitawati, Dewi, M.Y.C. dan Hartini, A.N. 2002. Potensi Mikroalga sebagai Bioindikator Tingkat Pencemaran Bahan Organik di Perairan Waduk. National Seminar on Research and Studies Research Grant conducted by Ministry of National Education, Directorate General of Higher Education, TPSDP, Jakarta December 27-28.

Retnaningdyah, C. dan Samino, S. 2005. Monitoring Dinamika Komunitas Fitoplankton dan Zooplankton di Waduk Sutami Malang Periode 2005. Laporan Penelitian Kerjasama Perum Jasa Tirta I dengan Jurusan Biologi Fakultas MIPA Universitas Brawijaya Sertifikat No. ID03/0127.

Retnaningdyah, C. dan Samino, S. 2006. Monitoring Dinamika Komunitas Fitoplankton dan Zooplankton di Waduk Sutami Malang Periode Bulan Januari-Maret 2006. Laporan Penelitian Kerjasama Perum Jasa Tirta I dengan Jurusan Biologi Fakultas MIPA Universitas Brawijaya Sertifikat No. ID03/0127.

Retnaningdyah, C., Marwati, U., Harnanto, A. dan Samino, S. 2007. Usaha Peningkatan Bioremediasi untuk Pengendalian Blooming Cyanobacteria Microcystis spp. di Perairan Tawar. Laporan Penelitian Program Insentif Riset Terapan. Penelitian dengan biaya Ristek.

Retnaningdyah, C. 2008. Keterkaitan Kualitas Air dengan Dinamika Populasi Microcystis spp. di Waduk Sutami, Malang, Jawa Timur. Prosiding Seminar Nasional Limnologi IV, diselenggarakan oleh Pusat penelitian Limnologi-LIPI, Bogor, 15 Oktober 2008. 
Retnaningdyah, C., Marwati, U., Samino, S., Partini, S. dan Hardi, Y.A.F. 2008. Respon Pertumbuhan Microcystis spp. dari Waduk Sutami pada Beberapa Variasi Media Pertumbuhan, Intensitas Cahaya dan Lama Penyinaran. Makalah dipresentasikan secara oral dalam Seminar Nasional Biodiversitas II, Universitas Airlangga, Surabaya 19 Juli 2008.

Romanowska-Duda, Z., Mankiewicz, J., Tarczyńska, M., Walter, Z. dan Zalewski, M. 2002. The Effect of Toxic Cyanobacteria (Blue Green Algae) on Water Plants and Animal Cells. Polish J. of Environmental Studies, 11 (5): 561-566.

Samino, S. dan Retnaningdyah, C. 2004. Monitoring Dinamika Komunitas Fitoplankton dan Zooplankton di Waduk Sutami Malang Periode Bulan Oktober sampai Desember 2004. Laporan Penelitian Kerjasama Perum Jasa Tirta I dengan Jurusan Biologi Fakultas MIPA Universitas Brawijaya Sertifikat No. ID03/0127.

Samino, S. dan Retnaningdyah, C. 2006. Evaluasi Sifat Toksik Microcystis spp. terhadap Beberapa Ikan dari Waduk Sutami untuk Pengembangan Early Warning System dalam Blooming Mikroalga. Laporan Penelitian Kerjasama Perum Jasa Tirta I dengan Jurusan Biologi Fakultas MIPA Universitas Brawijaya Sertifikat No. ID03/0127.
Sharpley, A.N. 2003. Agriculture and Phosphorus Management: the Chesapeaks Bay. CRC Press LLc. Boca Raton.

Smith, V.H. 1983. Low Nitrogen to Phosphorus Ratios Favor Dominance by Blue-green Algae in Lake. Science, 221: 669-671.

Soeprobowati, T.R. dan Hadisusanto, S. 2009. Diatom dan Paleolimnologi: Studi Komparasi Perjalanan Sejarah Danau Lac Saint-Augustine QuebeqCity, Canada dan Danau Rawa Pening Indonesia. Biota, 14 (1): 60-68.

Stahl-Delbanco, A., Hansson, L.A. dan Gyllstrom, M. 2003. Recruitment of Resting Stages may Induce Blooms of Microcystis at Low N:P Ratios. $J$. Plankton Res., 25 (9): 1099-1106.

Xie, L., Xie, P., Li, S., Tang, H. dan Liu, H. 2003. The Low TN:TP Ratio, a Cause or a Result of Microcystis Blooms?. Water Research 37: 2073-2080. 